\title{
A New Business Design Tool for Digital Business Model Innovation: DEA Approach
}

\author{
Ivano De Turi, ${ }^{1,2}$, Margaret Antonicelli ${ }^{2}$ \\ ${ }^{1}$ Lum Jean Monnet University, Bari, Italy \\ ${ }^{2}$ School of Management, Lum Jean Monnet University, Bari, Italy \\ Correspondence: Ivano De Turi Lum Jean Monnet University, Casamassima (Bari), SS. 100 km 18, Italy.
}

\author{
Received: April 2, 2020 \\ doi:10.5539/ibr.v13n6p86 \\ Accepted: May 9, $2020 \quad$ Online Published: May 20, 2020 \\ URL: https://doi.org/10.5539/ibr.v13n6p86
}

\begin{abstract}
The new economic structures characterized by the growing dynamics of the economic context and a greater influence of the market on entrepreneurial activities requires companies to generate and adopt more and more competitive innovations, to maintain and develop a high level of innovative activity. Innovations are perceived as a necessity, they are a factor, and they are the mobile strength of companies in the 21 st century. Every modern manager should recognize the role of innovations for the existence of companies and aim for innovative development. The news in various sectors must be followed. In this sense, it is necessary to look for options and overcome the obstacles that stand in the way of innovations. This paper attempts to assess the level of innovativeness of 26 European economies in the years 2016-2018 by using the Data Envelopment Analysis (DEA). To perform this study, the evaluation used was carried out on the basis of a summary index constructed with the use of statistical methods of non linear ordering; in particular. In the analysis carried out, the statistics of the Global Innovation Index were used to describe the innovative capacity of economies in two areas: (a) science and technology; and (b) education and training. The evolved classification of innovativeness of these countries, built on the basis of a synthetic index, will allow to create a ranking that will lead to comparative analysis among these countries.
\end{abstract}

Keywords: digital transformation, business model, innovation, data analysis, business design

\section{Introduction}

\subsection{Introduce the Problem}

In the last period the economic scenario has been the protagonist of radical changes in very fast times, which has progressed to the evolution of market conditions unpredictable. Companies then need to rethink and redefine their business model, identifying new paths of value generation, reformulating the approach to the market, reviewing the cost structure and configuring a flexible organizational structure and open to innovation (Iacovone, 2018). These views, together with the ever-changing consumer preferences and the emergence of new social trends, highlight that the correct and accurate definition of the business model is a fundamental element in the competitive success of a company. The growing coalition between the world of industries and the information technology world has generated the phenomenon of Industry 4.0 in the world of manufacturing companies. It make possible to create a close link between information, objects and people given by the approach of the virtual and physical world. According to some authors, the 4th industrial revolution will be the most powerful engine of innovation in the coming years. Therefore, Industry 4.0 features such as real-time capacity, horizontal and vertical interoperability, integration of production systems through ICT systems, are considered the answer to current challenges. In such a context, the future market position and profitability of companies will be the result of having identified and adopted an appropriate (innovative) business model, based on the opportunities offered by the new industrial revolution (Chesbrough, 2010; Osterwalder / Pigneur, 2010; George / Bock, 2011; Gassmann et al., 2013).

\subsection{Explore Importance of the Problem}

Having said that, it can be noted that it is necessary to adapt your organization to a systematic approach to business model innovation (BMI) that integrates the current practice of product and service innovation with greater capacity for the government and enhancement of new technologies. As a result, we expect this new 
approach to innovation to lead to new and dynamic value chain configurations, which will facilitate greater efficiency of resources and equipment and thus cost reductions, driven, for example, by the opportunity for flexible and dynamic reconfiguration of production capacity, a shorter time-to-market, higher scalability, lower waste rates or preventative maintenance. It's clear that the business models suitable for managing industry 4.0 processes have been put in place by focusing on customers, on creating value for customers, and on the data generated through new technologies. From the analysis of data relating to transactions with customers, the offers can be modeled on the basis of the specific needs of the customer or of an entire segment during the entire product life cycle. Use value chain data, processes become more flexible and more easily integrable with automation modules, allow companies to improve their resources and structures for creating value. IoT platforms will facilitate the creation of a greater number of data and services that can be used for create value from the collaboration. For companies operating in manufacturing supply chains, in particular, new IT facilities and in particular the ability to access information throughout the value chain and perform consolidated control offer new opportunities. Production can become more flexible with shorter cycle times and optimized networks with strategic options for new value propositions (e.g. Production on demand) and factor optimization. Companies must therefore be prepared to face the new scenarios in order to remain competitive in terms of globalization and intensifying competitiveness, based on the volatility of market demands, shortened innovation and the life cycles of products with increasing complexity in the processes. In this way, the fast digitization of the business world is breaking down traditional industry barriers, and many academics and professionals stress the need to reformulate the established business models. However, recent research focuses mainly on technological development and less on new business models that are emerging through the integration of technological innovations. This new industrial paradigm is transforming the current ways of creating value, as it involves changes in technical and product developments. These, in turn, have led to a wide organization of the consequences and opportunities, which provide more cooperative environments, improved customer relationships, and new product and service offerings. As a result, new and suitable business models are required. In addition, discussion and initiatives promoting the digital transformation of factories are on the rise among researchers, industries and policy makers around the world. In response to the growing interest in the topic and the need to deepen its understanding of its impact in Business Model Innovation, the literature was ready to address the problem with the following objectives: to have a clear vision of how Industry 4.0 affects business models and identify business and model innovations that result as a result. In Industry 4.0, a raw material plays a key role. But, unlike iron, pvc and other raw materials, this component is invisible. It is the intangible flows of industry-related data. With the correct means, firms can use this component to great advantage, as it gives them a way to continuously improve their processes. In addition, this data is the basis for new business models, making them the real revolution in the connected industry. At present, industry 4.0's focus is often on hardware.

This includes smartphones, tablets, fast computers, large memory, sensors, RFID technology and wireless connections. All these things make it possible to connect machines within factories and beyond national borders. However, these are issues that are not fully known to a large audience and not always technical. In fact, when we talk about Industry 4.0 we generally refer to real changes that affect design, research and development, production, with significant consequences on the flows associated with them. These changes are the source of new market pressures, but also from entrepreneurial insights. It is necessary to realize that more and more current will be the topics such as big-data and data analytics, digitalization, cloud computing, augmented reality, just to name a few, in terms of information management for value creation. On these assumptions, the need is based on understanding how much this metamorphosis, which is already in place, can impact internal processes and supply chain.

\subsection{Describe Relevant Scholarship}

Innovation is a broad term and has multiple meanings in academic research. Synthesizing the various variations, this can be summarized as "doing things differently". The business model concept meets the research area of innovation in two ways:

1. Acts as a facilitator for companies in order to market innovative ideas;

2. New forms of innovation are complemented by business models by combining traditional functions such as processes, products and organizational innovation with new themes of cooperation and collaboration.

The business model unlocks the potential of technological innovations within the company. Chesbrough has carried out a famous study that provides the comparison between successful and non-successful technological spin-offs. The study found that successful spin-offs are more likely when at the base, they have an effective 
business model than failed spin-offs that did not have a clear business model-defined strategy (H. Chesbrough, 2002). Innovation itself can also shape the business model: technological innovation triggers operational and commercial changes, which in turn change an organization's business model (Calia, Guerrini, \& Moura, 2007). Processes, products and organizational innovation with new themes of collaboration and collaboration. Innovation is also seen as the main driver of a change in the business model of an entire industry: for major industry changes, such as the movement of the fossil fuel economy to the clean economy, the business model should take into account technological innovations for the entire industry (Mark W Johnson \& Suskewicz, 2009). Innovation is important but not a guarantee of success (Doganova \& Eyquem-Renault, 2009), as it alone cannot create value in itself (H. Chesbrough, 2007; H. W. Chesbrough, 2007). Therefore, a business model must be designed solely to exploit the full commercial potential of an innovation and not an innovation as such. One aspect of the literature on the founding of the business model of extreme interest for the purpose of an overall analysis of the phenomenon is why companies continuously innovate their business models and the parts that make up it. Analyzing the impact of external factors on changing business models, De Reuver, Bouwman and Macinnes concluded that regulation and political/social forces had a lesser impact on the transformation of business models, while digital technologies played a predominant role as drivers of change (de Reuver, Bouwman, \& Maclnnes, 2009). One aspect of the literature on the founding of the business model of extreme interest for the purpose of an overall analysis of the phenomenon is why companies continuously innovate their business models and the parts that make up it. Analyzing the impact of external factors on changing business models, De Reuver, Bouwman and Maclnnes concluded that regulation and political/social forces had a lesser impact on the transformation of business models, while digital technologies played a predominant role as drivers of change (de Reuver, Bouwman, \& Maclnnes, 2009).

\subsection{State Hypotheses and Their Correspondence to Research Design}

In this paper we analyze firm's efficiency in European countries using the Data Envelopment Analysis (DEA), a methodology for analyzing the relative efficiency and managerial performance of productive (or response) units, having the same multiple inputs and multiple outputs. It allows us to compare relative efficiency of firms by determining the efficient firms which span the frontier. The most important advantage of DEA over traditional econometric frontier studies is that it is a non-parametric, deterministic method and, therefore, does not require a priori assumptions about the analytical form of the production function. Therefore, the probability of misspecification of the production technology is zero. The disadvantage is that, being a non-parametric method, it is more sensitive to possible mismeasurement problems (Jemric, Vujcic, 2002).

\section{The Evolutionary Steps of Business Modeling}

One often wonders how small startups can become dangerous for large multinational giants and how they manage to attack markets that until a decade ago seemed untouchable. The success of these companies is certainly not attributable to an improvement in the product system. Success, on the other hand, must be sought in the ability to rethink and innovate the logic with which the company creates and offers value to its customers. Simply put, those who have managed to innovate their company's business model win the market. Innovating your business model means understanding and rethinking the company at the highest level, as if you could climb a ladder and observe all the processes (production, distribution, commercial and so on) as a whole and in their synergies.

\subsection{The Business Model Canvas}

A tool that can pursue this innovation is the Business Model Canvas. The Business Model Canvas (BMC) is a strategic business design tool that uses visual language to create and develop innovative, high-value business models. The BMC allows you to represent visually how a company creates, distributes, and capture value for its customers. The nine blocks that make up the BMC represent all the links in the supply chain that every single company must weave in order to "create, distribute and capture value for the customer". And precisely from the customer segments (Customer Segments) from which we will start our analysis. An organization serves one or more customer segments. Customers are at the heart of any business model that can define one or more customer segments large or small. Value proposition describes the package of products and services that create value for a specific customer segment. Value Proposition is the reason customers turn to one company over another. Each Value Proposition consists of a selected set of products and/or services that meet the requirements of a specific customer. In this sense, the value proposition is a package of products or services that a company offers to customers. The value proposition reaches customers through appropriate communication, distribution and sales channels. Identifying these channels describes how a company communicates and reaches its customer segments to provide a value proposition. Customer Relationships are established and maintained with each customer 
segment. This customer channel describes the types of relationships that a company establishes with specific customer segments. A company should clarify the type of relationship it wants to establish with each customer segment. Revenue Streams, on the other hand, derive from successful value proxies offered to customers. Blocking revenue streams represents the money that a company generates from each customer segment. In addition, key resources are critical to the pursuit of the objective competitive advantage, which are the necessary resources that provide the elements described above. They are important for running a business model. These resources enable a business to create and oppose a value proposition, reach markets, maintain relationships with customer segments, and earn revenue. The Key activities building block describes some of the most important elements a company needs to do to make its business model work. Key tasks are the most important actions a company must take to operate successfully. The Key Partnership section describes the network of vendors and partners that allows the carrying out of business activities efficiently. Firms make collaborative choices for various reasons and partnerships increasingly represent a central element of all business models. In addition, firms form alliances to share skills and resources that can reduce risks and consolidate competitive advantage. The cost structure describes all the costs incurred to manage a business model. This building block describes the most important costs incurred during operation in a particular business model. The innovation of the nine business model blocks forms the basis for a useful tool, which we call the Business Canvas model. This tool resembles the canvas of a painter, preformed with the nine blocks, which allows you to paint images of new or existing business models. But the canvas business model is just one of the tools used in business design. The great potential of this tool comes from the possibility of being used as a basis for the development of custom "tele" for different types of utilities and peculiarities (Osterwalder, Pigneur, 2010).

\subsection{The Business Design}

This section describes a number of design world techniques and tools that can help you design better and more innovative business models. The activity of a designer implies an incessant investigation in the best way to generate for something new, discover the unknown or obtain the appropriate design. The job of a designer is to broaden the boundaries of the way of thinking, create new alternatives and, ultimately, create value for users. This need for an ability to think about "what does not exist". We believe that the resources and attitude of the design profession are the prerequisites for success in generating the business model. Businessmen have to deal with design every day without knowing it. By defining a strategy, structuring the organizational apparatus or simply writing a project. We design organizations, strategies, business models, processes and projects. To do this, we need to consider a complex network of factors, such as competitors, technology, the legal environment and more. Increasingly, we must do so in the unknown and unexplored territory. That's exactly what design is about. What business people lack is designing tools that complement their entrepreneurial skills. The following pages illustrate six business model design techniques: Customer Insights, Ideation, Visual Thinking, Prototyping, Storytelling, and Scenarios. Firms invest heavily in market research, but often end up not taking the customer's point of view into consideration when designing products, services and business models. The good design of the business model prevents that this happens. What is observed in the business model through the eyes of customers is a criterion that can lead to the discovery of completely new opportunities. This does not mean that customer thinking is the main source of an innovative idea, but it is very important to take it into account. Successful innovation requires an in-depth analysis of customer needs, including the environment, habits, pains and ambitions.

\subsection{The Design Thinking}

Another methodology for solving complex problems with which creative attitudes are combined with analytical skills is Design Thinking (DT). The DT promotes a design process which, although with different variations, has five fundamental phases.The first step is to identify the problem and therefore the goal. The second in identifying the context, defining key data and actors. The third in the analysis and search for opportunities. The fourth in the conception, prototyping, testing and validation and the last in the realization of the product / service. The various steps involve generating many ideas (including selecting the best ones) in brainstorming sessions (which can involve, in addition to the designers, customers and other people of the company) with the focus on "human" needs. The process is not linear but recursive: any return to the previous steps is expected based on the results of the prototyping and testing phases. It is essential to understand that the five phases need not be sequential. It's not necessary to follow a specific order and they can occur in parallel and / or be repeated several times. This simply means that the design team constantly uses the results to restructure, interrogate and implement initial assumptions and results. 


\section{Creating a SD4.0 Canvas}

This methodology developed by the Stanford Institute of Design is extremely useful for the identification and development of new business models based on resources, activities and objectives. By combining the method of Design Thinking with the tools of the Business model canvas, it was possible to create a dedicated canvas able to collect the contributions of the actors participating in the SD4.0 focus groups (companies, institutional actors in the area, experts) for the design and pilot implementation. Specifically, the canvas that was developed by the Lum Enterprise team incorporates all the building blocks necessary to collect emerging reflections both in the brainstorming phase and in the phase of consolidation and integration of the contributions. The defined structure sees in the upper part the identification of the problem (called case study) and the objectives that are to be pursued through it, the intermediate part develops from left to right starting from the identification of the starting context (process as-is ) and then declining key activities and resources \& skills. The opportunities deriving from existing and / or developable tools for the expected results of the operation are also mapped. In the last part of the canvas, the cost structure (as-is and destined for the project) and the revenue perspectives intended in a broader sense with the term benefits are included, specularly to the BMC. It is reported below the Canvas SD4.0.

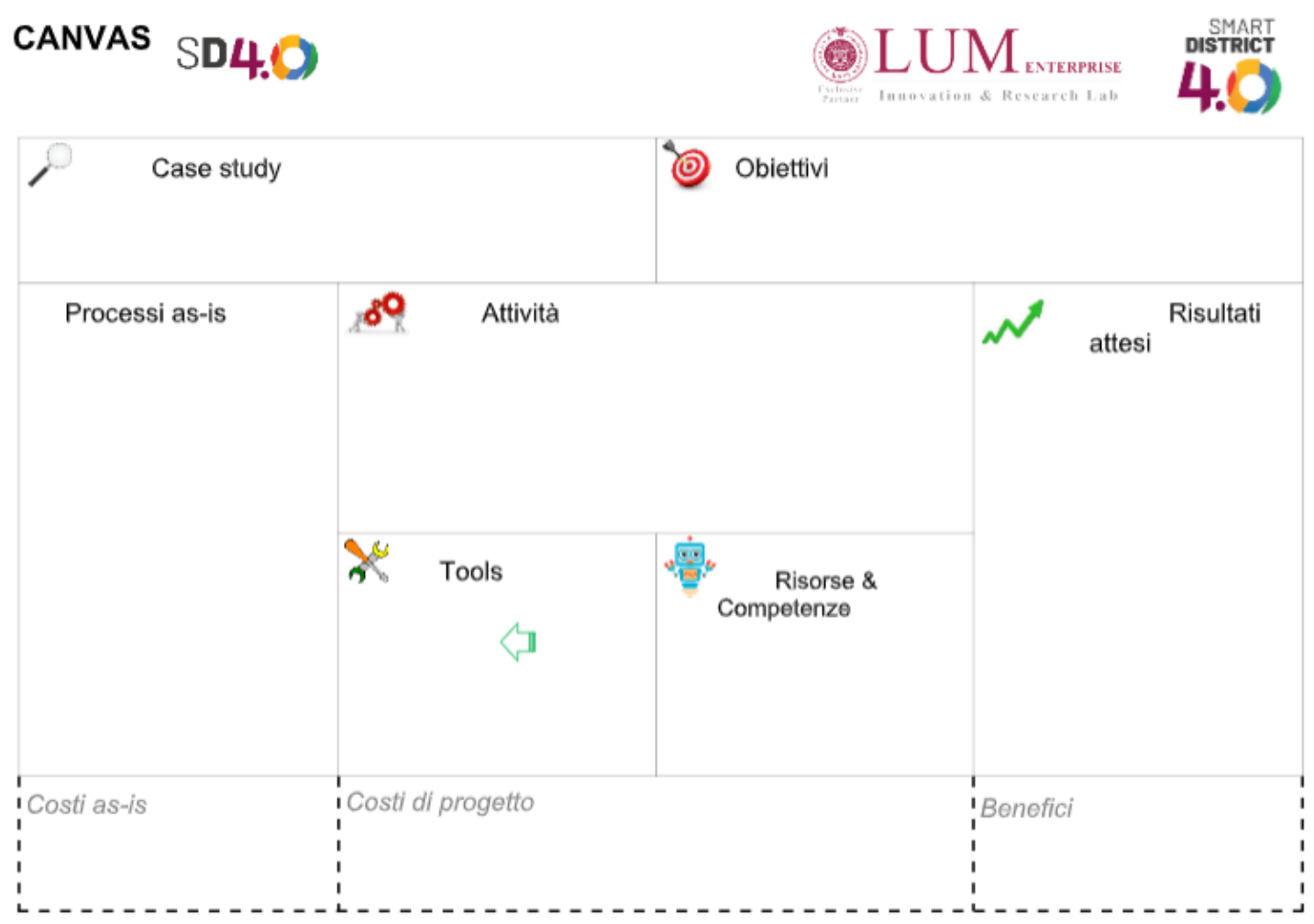

Figure 1. Canvas SD4.0 - Processing of the authors

The compilation order is from top to bottom, and from left to right. In detail, the individual building blocks of the Canvas SD4.0 aim to weave the main parts of the process in order to identify their main characteristics. In detail: 
Table 1. Description of the Canvas SD4.0 building blocks

\begin{tabular}{|c|c|}
\hline Block title & Description \\
\hline Case study & $\begin{array}{l}\text { This section describes the problem or process that you want to analyze and } \\
\text { implement within the design (e.g. traceability of the production process with } \\
\text { blockchain, preparation of a predictive maintenance system, ...) }\end{array}$ \\
\hline Goals & $\begin{array}{l}\text { The "objectives" building block must contain the prospects for improvement } \\
\text { planned and articulated according to the entrepreneur's expectations (e.g. increasing } \\
\text { the levels of data security, overcoming privacy problems, servicing, ...). }\end{array}$ \\
\hline As-is processes & $\begin{array}{l}\text { This block is essential to frame the state of the art of the problem / process being } \\
\text { analyzed at the beginning of the design of a new solution with a focus on the } \\
\text { characteristics of the processes that will be subject to revision and implementation } \\
\text { (e.g. management program not integrated with logistics, corrective maintenance } \\
\text { system without data analysis, ...). }\end{array}$ \\
\hline Activities & $\begin{array}{l}\text { By tools we mean all the tools useful to prepare the environment and context for the } \\
\text { implementation of new processes (e.g. business intelligence tools, IoT sensors, data } \\
\text { analysis tools, ...) }\end{array}$ \\
\hline Tools & $\begin{array}{l}\text { By tools we mean all the tools useful to prepare the environment and context for the } \\
\text { implementation of new processes (e.g. business intelligence tools, IoT sensors, data } \\
\text { analysis tools, ...) }\end{array}$ \\
\hline Resources \& Competencies & $\begin{array}{l}\text { In this block it is appropriate to insert the necessary skills and / or the key resources } \\
\text { necessary to use and enhance the role of the tools in the context of the new } \\
\text { processes installed in order to pursue the expected results (e.g. data scientist, } \\
\text { domain expert, data analyst ,...) }\end{array}$ \\
\hline Expected results & $\begin{array}{l}\text { The expected results must be clearly described in prospective terms and in relation } \\
\text { to the objectives set. In detail, the outputs expected from the new process must be } \\
\text { highlighted (ex. Alert relating to the malfunction of the machinery, advanced } \\
\text { inventory management, automatic warehouse restock, ...) }\end{array}$ \\
\hline$A s$-is costs & $\begin{array}{l}\text { In this section, only the costs relating to the "as-is processes" block, or all the costs } \\
\text { that were incurred for carrying out the production phase or the process being } \\
\text { analyzed and implemented, will be included. }\end{array}$ \\
\hline Project costs & $\begin{array}{l}\text { In this block the costs to be incurred for the development of the project will be } \\
\text { defined and in detail the sum of the costs relating to the contents of the sections: } \\
\text { activities, tools and resources \& skills. }\end{array}$ \\
\hline Revenues & $\begin{array}{l}\text { Finally, the benefits deriving from the adoption of the new model will be identified } \\
\text { in the benefits box. These advantages may be expressed both in monetary terms and } \\
\text { in terms of efficiency of the processes in relation to the time and / or quality of the } \\
\text { data collected in terms of accuracy of the analyzes that will derive from it. }\end{array}$ \\
\hline
\end{tabular}

Note. The use of the Canvas SD4.0 will be ideal in work tables (focus groups, brainstorming lab, ....) where it will be necessary to deal with issues of digital innovation and digital transformation of simple or complex business processes and procedures. The interface created is easy to understand and intuitive to use even for participants with non-digital skills.

\section{Methodology}

The Data Envelopment Analysis (DEA) is a mathematical programming model applied to observational data that provides as a new way of obtaining empirical estimates of relations - such as the production function and/or efficient production possibility surfaces - that are cornerstones of modern economics (Charnes, Cooper, Rhodes, 1978). Scientific studies identify two different DEA methodologies to assess efficiency frontier: stochastic analysis and the deterministic analysis. In the context of deterministic frontiers DEA is by far the most used technique. This statistical method, based on extreme observations, provides a different approach to regression analysis beacuse is a non-parametric, deterministic methodology for determining the relatively efficient production frontier, based on the empirical data on chosen inputs and outputs of a number of entities, called 
Decision Making Units (DMUs): a group of people in a company or other organization who are responsible for making important decisions, especially decisions about whether to buy something. Based on available data, DEA identifies reference points (relatively efficient DMUs) that define the efficient frontier and evaluate the inefficiency of other, interior points (relatively inefficient DMUs) that are below that frontier. The main advantage of DEA is that it does not require a priori assumption about the analytical form of the production function. Instead, it constructs the best practice production function solely on basis of observed data and therefore it is not possible to misspecify the production technology. The main disadvantage of DEA is that the frontier is sensitive to extreme observations and measurement errors since the basic assumption is that random errors do not exist and that all deviations from the frontier indicate inefficiency. In the regression approach a single estimated regression equation is assumed to apply to each observation vector. DEA analyzes each vector (DMU) separately, producing individual efficiency measures relative to the entire set under evaluation. There are numerous DEA models. We use the two most frequently those used: the input-oriented approach, the output-oriented approach, the CCR model (after Charnes, Cooper, Rhodes, 1978) and the BCC model (after Banker, Charnes and Cooper, 1984). In this study it was decided to use the input oriented model which estimates the efficiency level of the individual DMUs in terms of reduction in inputs with the same output.

An economyc unit can be technically inefficiencies not only if it wastes input during the production (input orientation), but even if, given the inputs, it does not maximize the output (output oriented).

With the DEA methodology, the efficiency of an operating unit is measured with reference to a "non-paramentric" production function using appropriate Linear Programming techniques. Given a production function that, for a given technology, transforms an input vector into an output vector, an input-output vector is technically efficient only and only if it is possible to increase the output obtained (or decrease the input used), only by reducing another output (or increasing another input).

Each DMU consumes a different amount of input $m$ and produces a different amount of output: DMUj consumes $\mathrm{x}_{\mathrm{ij}}$ input quantity $(\mathrm{j}=1, \ldots, \mathrm{m})$ to produce $\mathrm{y}_{\mathrm{jr}}$ output quantity $(\mathrm{j}=1, \ldots, \mathrm{s})$ with $\mathrm{x}_{\mathrm{ij}} \geq 0, \mathrm{y}_{\mathrm{rj}} \geq 0$. In this way, the determination of the efficiency of each single DMU requires the identification of the corresponding virtual DMU $\left(\mathrm{DMU}_{\mathrm{j}} *\right)$ on the efficient frontier. Inputs and outputs of each $\mathrm{DMU}_{\mathrm{j}}$ * can be expressed as a linear combination of the inputs and outputs of the other DMUs observed in the sample:

$$
x_{j i}=j=1 n \lambda_{i} x_{j i} \text { with } \mathrm{i}=1 \ldots . . ., m \quad y_{j r}=j=1 n \lambda_{i} y_{j r} \text { with } i=1 \ldots . ., s
$$

\subsection{Specification of the Data}

This paper attempts to assess the level of innovativeness of 26 European economies in the years 2016-2018. As the statistical basis for the input and output data, both the average of the operating revenues and the average of the employees for each country and the data of the survey on the global innovation index are used. An input oriented approach will be used in this study. In detail, the variables used are:

- global innovation index (GII): expressed by a composite indicators, aims to capture the multi-dimensional facets of innovation and provide the tools that can assist in tailoring policies to promote long-term output growth, improved productivity, and job growth. Five input pillars capture elements of the national economy that enable innovative activities: (1) Institutions, (2) Human capital and research, (3) Infrastructure, (4) Market sophistication, and (5) Business sophistication. Two output pillars capture actual evidence of innovation outputs: (6) Knowledge and technology outputs and (7) Creative outputs. (Source: www.globalinnovationindex.org);

- revenue: expressed in terms of the average amount of sales by country calculated for each year (Source: Amadeus);

- employees: expressed in terms of firms' average number of employees, has been calculated for each country and year (Source: Amadeus).

For each ( $\mathrm{j}_{\mathrm{th}}$ ) Decision Making Unit (i.e. for each country ) the input data ( $\mathrm{x}$ ) are:

- Input 1 -global innovation index and operating revenue

- Input 2 -global innovation index and employees

\section{Results}

For the purposes of the DEA, the most efficient DMUs (which from now on we will call economies or countries) are identified as having the lowest values. The efficiency measure of each DMU is represented by the ratio 
between the minimum input necessary to obtain a precise output and the one actually used: it is a proportional reduction factor to be applied to all inputs to obtain, for the same output, a production process efficient (Farrell oriented index). Sweden is leading in 2016 the rankings, moving the United Kingdom high. Finland, Ireland, Denmark and the Netherlands follow.

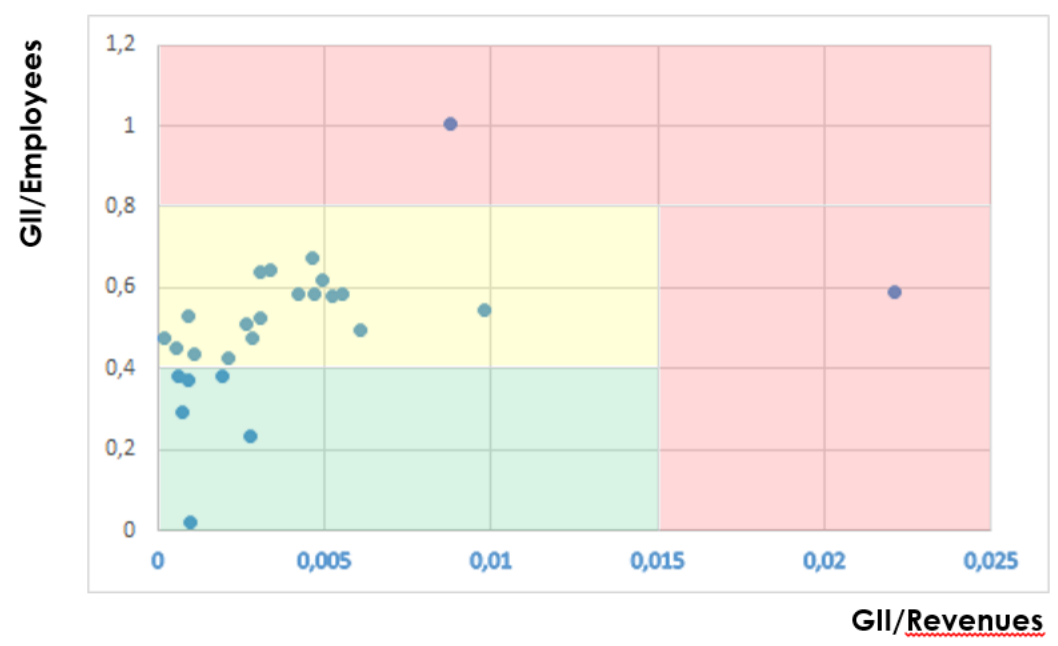

Figure 2. DEA model, input oriented, European country, 2016

Germany follows these economies together with Luxembourg. Eastern European countries rank, as outliers, in the last places, positioning themselves in the upper quadrants of the model.

Table 2. DEA input oriented indicator results, European country, 2016

\begin{tabular}{lrr}
\hline \multicolumn{1}{c}{ Country } & GII/Revenue & \multicolumn{1}{c}{ GII/Employees } \\
\hline Austria & 0,001094475 & 0,438196761 \\
Belgium & 0,000933421 & 0,531391347 \\
Bulgaria & 0,022105188 & 0,588633283 \\
Croatia & 0,009815201 & 0,54439154 \\
Czechia & 0,005563576 & 0,58248744 \\
Denmark & 0,000593009 & 0,380271876 \\
Estonia & 0,00879288 & 1,006581235 \\
Finland & 0,00284476 & 0,473773742 \\
France & 0,000984369 & 0,020807851 \\
Germany & 0,000893797 & 0,371026007 \\
Greece & 0,002665856 & 0,512701378 \\
Hungary & 0,005231416 & 0,580225893 \\
Ireland & 0,000581304 & 0,451335059 \\
Italy & 0,003058016 & 0,641417535 \\
Latvia & 0,00495277 & 0,620664482 \\
Lithuania & 0,004673268 & 0,585638269 \\
Luxembourg & 0,001911174 & 0,382917229 \\
Malta & 0,003375365 & 0,644398274 \\
Netherlands & 0,000226231 & 0,475257516 \\
Poland & 0,002751529 & 0,230696534 \\
Portugal & 0,004645187 & 0,675415623 \\
Romania & 0,006074566 & 0,496677057 \\
Slovakia & 0,004218837 & 0,584230465 \\
Spain & 0,003061818 & 0,524210523 \\
Sweden & 0,002128733 & 0,426506756 \\
United Kingdom & 0,000738811 & 0,294529944 \\
\hline & & \\
\hline
\end{tabular}


In 2017, the GII remains relatively stable at the top. Netherlands leads the rankings, while Sweden maintains the second place. The United Kingdom slightly worsens its position, while Denmark gets better. Finland and Ireland move upwards, while Germany continues its progress.

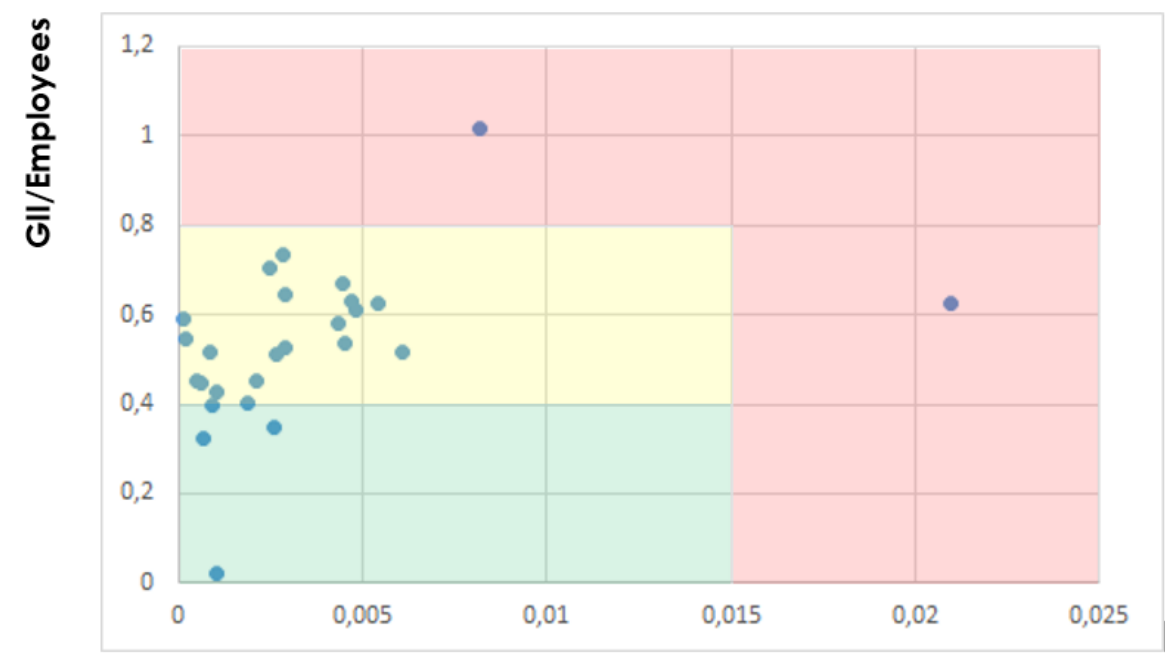

GII/Revenues

Figure 3. DEA model, input oriented, European country, 2017

Table 3. DEA input oriented indicator results, European country, 2017

\begin{tabular}{lrr}
\hline \multicolumn{1}{c}{ Country } & GII/Revenue & \multicolumn{1}{c}{ GII/Employees } \\
\hline Austria & 0,001022325 & 0,428512565 \\
Belgium & 0,000852663 & 0,514711838 \\
Bulgaria & 0,020931759 & 0,62394589 \\
Croatia & 0,000156016 & 0,589471695 \\
Czechia & 0,004807447 & 0,608708555 \\
Denmark & 0,000526981 & 0,451081252 \\
Estonia & 0,008157062 & 1,014518608 \\
Finland & 0,002633822 & 0,511652968 \\
France & 0,001027792 & 0,020435453 \\
Germany & 0,000945732 & 0,39600592 \\
Greece & 0,002454291 & 0,704092664 \\
Hungary & 0,004539214 & 0,534704466 \\
Ireland & 0,00058999 & 0,448523674 \\
Italy & 0,002924159 & 0,645236093 \\
Latvia & 0,004678711 & 0,629224728 \\
Lithuania & 0,004322038 & 0,581256924 \\
Luxembourg & 0,001895527 & 0,400646708 \\
Malta & 0,002859752 & 0,735405733 \\
Netherlands & 0,000194253 & 0,548228496 \\
Poland & 0,002625311 & 0,348307413 \\
Portugal & 0,004441115 & 0,67103486 \\
Romania & 0,006104781 & 0,518034 \\
Slovakia & 0,005412389 & 0,62614014 \\
Spain & 0,002920599 & 0,525972808 \\
Sweden & 0,002144231 & 0,45321383 \\
United Kingdom & 0,000694855 & 0,32561047 \\
\hline
\end{tabular}

It is possible to summarize the movements of the top 10 economies as follows:

1. Sweden, 2. Netherlands, 3. United Kingdom, 4. Denmark, 5. Finland, 6. Germany, 7.Ireland, 8. France, 9. Norway, 10. Czech Republic

Belgium suffered a setback worsening its position.

A look at the 2018 GII ranking highlights the surprising presence of several countries or economies with small populations or relatively small economies. Among the former, one can find, for example, the Netherlands, Northern Europe countries and Luxembourg — despite the fact that large economies like the United Kingdom and 
Germany, they are also part of this group.

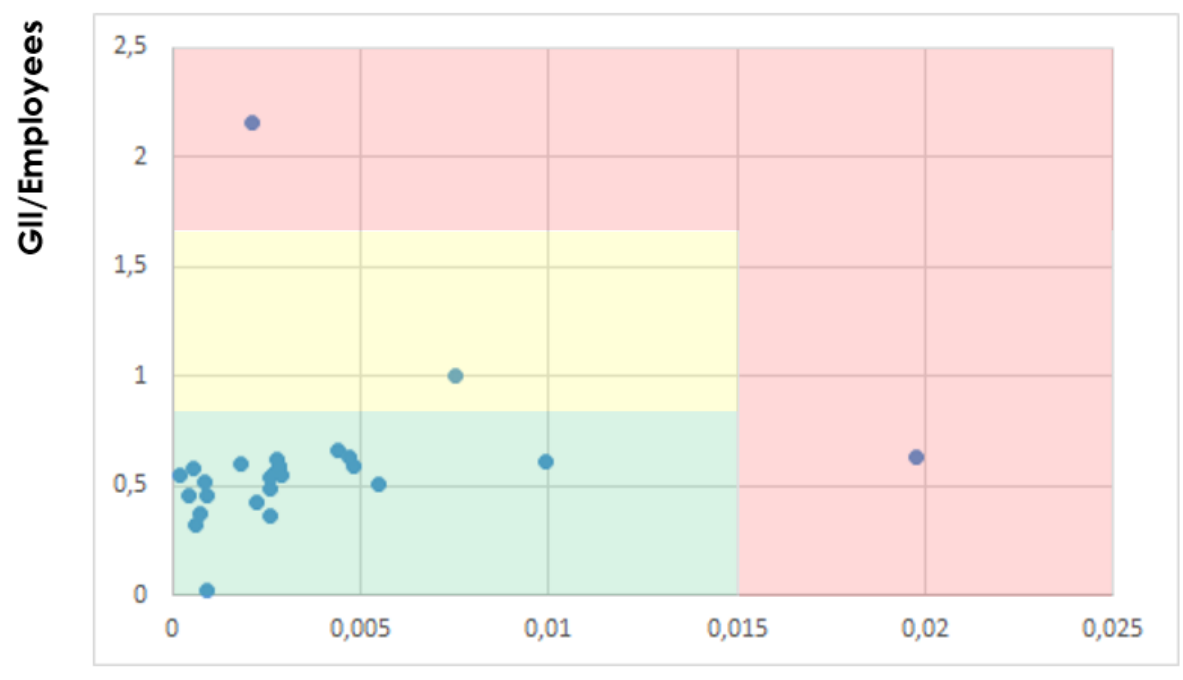

GII/Revenues

Figure 4. DEA model, input oriented, European country, 2018

Like last year, the best economies are the Netherlands, and Sweden followed by the United Kingdom, Finland, Denmark, Germany, Ireland, Luxembourg, France, Norway, Austria, Iceland,Estonia and Belgium. It is crucial to emphasize that most of the economies in this region they have the least number of missing values, leading them to view the most accurate GII rankings. This includes the following economies with $100 \%$ data coverage in innovation Sub-index, Innovation output sub-index, or both.

Table 4. DEA input oriented indicator results, European country, 2018

\begin{tabular}{lrr}
\hline \multicolumn{1}{c}{ Country } & GII/Revenue & \multicolumn{1}{c}{ GII/Employees } \\
\hline Austria & 0,000939954 & 0,459031739 \\
Belgium & 0,000829577 & 0,51665498 \\
Bulgaria & 0,019726899 & 0,631344886 \\
Croatia & 0,009925488 & 0,60942729 \\
Czechia & 0,00283442 & 0,577228214 \\
Denmark & 0,000444209 & 0,458544892 \\
Estonia & 0,007501578 & 1,002650686 \\
Finland & 0,002594937 & 0,543998497 \\
France & 0,000912177 & 0,02075295 \\
Germany & 0,00076088 & 0,372872911 \\
Greece & 0,001804057 & 0,597175013 \\
Hungary & 0,004801586 & 0,591024381 \\
Ireland & 0,000585473 & 0,582322894 \\
Italy & 0,002757754 & 0,623161552 \\
Latvia & 0,002825111 & 0,586843702 \\
Lithuania & 0,002694318 & 0,559675012 \\
Luxembourg & 0,00222866 & 0,424114957 \\
Malta & 0,002092337 & 2,155714286 \\
Netherlands & 0,000176451 & 0,546840178 \\
Poland & 0,002603205 & 0,360684682 \\
Portugal & 0,004402963 & 0,664863239 \\
Romania & 0,005458635 & 0,50666589 \\
Slovakia & 0,004709454 & 0,637494026 \\
Spain & 0,002905075 & 0,550766389 \\
Sweden & 0,002580338 & 0,491039519 \\
United Kingdom & 0,000645134 & 0,318906738 \\
\hline
\end{tabular}




\section{Conclusions}

It is now common wisdom that science and innovation are more internationalized and collaborative than ever before. All stand to gain from global innovation. First, more innovation investments are conducted today than at any other time. Second, through international openness, the potential for global knowledge spillovers are on the rise. Finally, innovation actors in emerging countries now make meaningful contributions to local and global innovation.

\section{Acknowledgments}

We thank all the team of Lum Enterprise (academic spin-off of Lum Jean Monnet University) for their contribution to the conduct of the study or to the criticism of the manuscript.

\section{References}

Airaksinen, A., Luomaranta, H., Alajääskö, P., \& Roodhuijzen, A. (2015). Statistics on small and medium-sized enterprises, Dependent and independent SMEs and large enterprises. Eurostat. Retrieved November 15, 2016, from http://ec.europa.eu/eurostat/statistics-explained

Alcácer, J., Cantwell, J., \& Piscitello, L. (2016). Internationalization in the information age: A new era for places, firms, and international business networks? J Int Bus Stud, 47, 499-512. https://doi.org/10.1057/jibs.2016.22

Alexandre, M., Samir, L., Robert, P., Romain, E., \& Simon, T. (2017). Industry 4.0 and the SME: a technology-focused review of the empirical literature. 7th International Conference on Industrial Engineering and Systems Management IESM, Oct 2017, Saarbrücken, Germany. 〈hal-01836173〉

Arnold, C., Kiel, D., \& Voigt, K. I. (2016). How the industrial internet of things changes business models in different manufacturing industries. International Journal of Innovation Management, 20(08), 1640015. https://doi.org/10.1142/S1363919616400156

Baines, T. S., Lightfoot, H. W., Benedettini, O., \& Kay, J. M. (2009). The servitization of manufacturing: A review of literature and reflection on future challenges. Journal of Manufacturing Technology Management, 20(5), 547-567. https://doi.org/10.1108/17410380910960984

Baines, T., \& Lightfoot, H. W. (2014). Servitization of the manufacturing firm: Exploring the operations practices and technologies that deliver advanced services. International Journal of Operations \& Production Management, 34(1), 2-35. https://doi.org/10.1108/IJOPM-02-2012-0086

Barann, B., Hermann, A., Cordes, A. K., Chasin, F., \& Becker, J. (2019, January). Supporting Digital Transformation in Small and Medium-sized Enterprises: A Procedure Model Involving Publicly Funded Support Units. In Proceedings of the 52nd Hawaii International Conference on System Sciences.

Boland, R. J. J., \& Collopy, F. F. (2004). Design Matters for Management, Managing as Designing. Stanford University Press, 3-18.

Boyce, C., \& Neale, P. (2006). Conducting in-depth interviews: A guide for designing and conducting in-depth interviews for evaluation input.

Bracalente, B., Cossigani, M., \& Mulas, A. (2014). Statistica Aziendale. McGraw Hill.

Buonanno, G., Faverio, P., Pigni, F., Ravarini, A., Sciuto, D., \& Tagliavini, M. (2005). Factors affecting ERP system adoption: A comparative analysis between SMEs and large companies. Journal of Enterprise Information Management, 18(4), 384-426. https://doi.org/10.1108/17410390510609572

Carlborg, P., Kindström, D., \& Kowalkowski, C. (2013). A lean approach for service productivity improvements: synergy or oxymoron? Managing Service Quality: An International Journal, 23(4), 291-304. https://doi.org/10.1108/MSQ-04-2013-0052

Cha, K. J., Hwang, T., \& Gregor, S. (2015). An integrative model of IT-enabled organizational transformation: A multiple case study. Management Decision, 53(8), 1755-1770. https://doi.org/10.1108/MD-09-2014-0550

Charnes, A., Cooper, W. W., \& Rhodes, E. (1978). Measuring the efficiency of decision making units (pp. 429-444). European Journal of Operational Research. https://doi.org/10.1016/0377-2217(78)90138-8

Chen, J. E., Pan, S. L., \& Ouyang, T. H. (2014). Routine reconfiguration in traditional companies' e - commerce strategy implementation: A trajectory perspective. Information Management, 51(2), 270-282. https://doi.org/10.1016/j.im.2013.11.008

Chesbrough, H. (2010). Business Model Innovation: Opportunities and Barriers. Long Range Planning, 43(2-3), 
354-363. https://doi.org/10.1016/j.lrp.2009.07.010

Ciborra, C. U., Braa, K., Cordella, A., Dahlbom, B., Failla, A., \& Hanseth, O. et al. (Eds.). (2001). From Control to Drift. The Dynamics of Corporate Information Infrastructures, New York: Oxford University Press.

Cooper, L. E. P. (1997). Supply Chain Management: More than a new name for logistics. International Journal of Logistics Management. https://doi.org/10.1108/09574099710805556

Cooper, W. W., Seiford, L. M., \& Zhu, J. (2001). Handbook on Data Envelopment Analysis (2nd ed.). Springer International Series in Operations Research \& Management.

Coyle, J. J., Bardi, E. J., \& Langley, C. J. (1988). The management of business logistics. St. Paul,West Publishing Company.

Crotty, M. (1998). The foundations of social research: Meaning and perspective in the research process. Sage.

Dehning, B. et al. (2013). The Value Relevance of Announcements of Transformational Information Technology Investments. MIS Quarterly, 27(4), 637-656. JSTOR. https://doi.org/10.2307/30036551

Demartini, P., \& Paoloni, P. (2013). Implementing an intellectual capital framework in practice. Journal of Intellectual Capital, 14(1), 69-83. https://doi.org/10.1108/14691931311289020

Dosi, G. (1982). Technological paradigms and technological trajectories: a suggested interpretation of the determinants and directions of technical change. Research policy, 11(3), 147-162. https://doi.org/10.1016/0048-7333(82)90016-6

Eisenhardt, K. M. (1989). Building Theories from Case Study Research. Academy of Management Review, 14(4), 532-550. Exclusión y desarraigo. Universidad Nacional de Colombia, Oficina del Alto (1989). https://doi.org/10.5465/amr.1989.4308385

Eisenhardt, K. M. (2002). Building theories from case. The qualitative researcher's companion, 5(36).

Ekbia, H. R. (2009). Digital artifacts as quasi - objects: Qualification, mediation, and materiality. Journal of the American Society for Information Science and Technology, 60(12), 2554-2566. https://doi.org/10.1002/asi.21189

Farrel, M. J. (1957). The measurement of productive efficiency. Journal of the Royal Statistical Society, 120, 253-290. https://doi.org/10.2307/2343100

Fleisch, E., Weinberger, M., \& Wortmann, F. (2014). Business Models and the Internet of Things, St. Gallen: Bosch Internet of Things \& Services Lab Universität St. Gallen. https://doi.org/10.1007/978-3-319-16546-2_2

Frank, A. G., Mendes, G. H., Ayala, N. F., \& Ghezzi, A. (2019). Servitization and Industry 4.0 convergence in the digital transformation of product firms: A business model innovation perspective. Technological Forecasting and Social Change, 141, 341-351. https://doi.org/10.1016/j.techfore.2019.01.014

Galbraith, J. (1973). Designing complex organizations. Reading, MA: Addison-Wesley.

Gassmann, O., Frankenberger, K., \& Csik, M. (2013). Geschätsmodelle entwickeln - 55 innovative Konzepte mit dem St. Galler Business Model Navigator. München: Hanser. https://doi.org/10.3139/9783446437654

George, G., \& Bock, A. J. (2011). The Business Model in Practice and its Implications for Entrepreneurship Research, in: Entrepreneurship: Theory \& Practice, 35(1), 83-111. https://doi.org/10.1111\%2Fj.1540-6520.2010.00424.x

Gerald, K. (2019). The Technology Fallacy, Research. Technology Management, 62(6), 44-49. https://doi.org/10.1080/08956308.2019.1661079

Gilmore, A., Carson, D., O’Donnell, A., \& Cummins, D. (1999). Added value: a qualitative assessment of SME marketing. Irish Marketing Review, 12(1), 27-35.

Glaser, B. G., \& Strauss, A. L. (1967). The discovery of grounded theory: Strategies for qualitative research. Chicago: Aldire. https://doi.org/10.1097/00006199-196807000-00014

Hanseth, O., \& Lyytinen, K. (2010). Design theory for dynamic complexity in information infrastructures: the case of building internet. Journal of information technology, 25(1), 1-19. https://doi.org/10.1057/jit.2009.19

Kallinikos, J. et al. (2013). The Ambivalent Ontology of Digital Artifacts. MIS Quarterly, 37(2), 357-370., https://doi.org/10.25300/MISQ/2013/37.2.02

Kim, W. C., \& Mauborgne, R. (2004). Blue Ocean strategy: how to create uncontested market space and make 
competition irrelevant. Harvard Business School Press, Boston.

Lasi, H., Fettke, P., \& Kemper, H. et al. (2014). Industry 4.0. Bus Inf Syst Eng, 6, 239-242. https://doi.org/10.1007/s12599-014-0334-4

Lee, H. J. (2012). A review of value creating motive and business model in smart technology. In Park, Y. H., Jin. Q., Yeo, M. S., \& Hu, B. (Eds.), Human centric technology and service in smart space (pp. 159-163). New York, NY: Springer. https://doi.org/10.1007/978-94-007-5086-9_21

Li, L., Su, F., Zhang, W., \& Mao, J. Y. (2018). Digital transformation by SME entrepreneurs: A capability perspective. Information Systems Journal, 28(6), 1129-1157. https://doi.org/10.1111/isj.12153

Liao, Y., Deschamps, F., Loures, E. D. F. R., \& Ramos, L. F. P. (2017). Past, present and future of Industry 4.0-a systematic literature review and research agenda proposal. International journal of production research, 55(12), 3609-3629. https://doi.org/10.1080/00207543.2017.1308576

Lombardi, R. (2019). Knowledge transfer and organizational performance and business process: past, present and future researches. Business Process Management Journal, 25(1), 2-9. https://doi.org/10.1108/BPMJ-02-2019-368

Lu, Y. (2017). Industry 4.0: A survey on technologies, applications and open research issues. Journal of Industrial Information Integration, 6, 1-10. https://doi.org/10.1016/j.jii.2017.04.005

Lucas, H. et al. (2013). Impactful Research on Transformational Information Technology: An Opportunity to Inform New Audiences. MIS Quarterly, 37(2), 371-382. https://doi.org/10.25300/MISQ/2013/37.2.03

Markides, C., \& Charitou, C. (2004). Competing with dual business models: A contingency approach. Academy of Management Executive, 18, 22-36. https://doi.org/10.5465/ame.2004.14776164

Mikalef, P., Pappas, I. O., \& Krogstie, J. et al. (2018). Big data analytics capabilities: a systematic literature review and research agenda. Inf Syst E-Bus Manage, 16, 547-578. https://doi.org/10.1007/s10257-017-0362-y

Müller, J. M., Buliga, O., \& Voigt, K. I. (2018). Fortune favors the prepared: How SMEs approach business model innovations in Industry 4.0. Technological Forecasting and Social Change, 132, 2-17. https://doi.org/10.1016/j.techfore.2017.12.019

Myers, M. D., \& Avison, D. (Eds.). (2002). Qualitative research in information systems: a reader. Sage. https://doi.org/10.4135/9781849209687

Nambisan, S. (2017). Digital entrepreneurship: Toward a digital technology perspective of entrepreneurship. Entrepreneurship Theory and Practice, 41(6), 1029-1055. https://doi.org/10.1111/etap.12254

Neuhofer, B., Buhalis, D., \& Ladkin, A. (2015). Smart technologies for personalized experiences: a case study in the hospitality domain. Electron Markets, 25, 243-254. https://doi.org/10.1007/s12525-015-0182-1

O’Reilly, C. A., \& Tushman, M. L. (2004). The ambidextrous organization. Harvard Business Review, April: 74-83.

Osterwalder, A., \& Yves, P. (2010). Business model generation: a handbook for visionaries, game changers, and challengers. John Wiley \& Sons.

Parker, G. G., Marshall, W. V. A., \& Sangeet, P. C. (2016). Platform Revolution: How Networked Markets Are Transforming the Economy? and How to Make Them Work for You. WW Norton \& Company, 2016.

Pettigrew, A. (1988). Longitudinal Field Research on Change, Theory and Practice. Paper Presented at the National Science Foundation Conference on Longitudinal Research Methods on Organizations. Austin, Texas, USA. https://doi.org/10.1287/orsc.1.3.213

Pinna, R. (2006). L'evoluzione nella dimensione organizzativa della supply chain: dalla gestione di un flusso alla gestione di una rete. F. Angeli, 2006.

Porter, M. E., \& James, E. H. (2014). How smart, connected products are transforming competition. Harvard business review, 92(11), 64-88.

Radziwon, A., Bilberg, A., Bogers, M., \& Madsen, E. S. (2014). The smart factory: exploring adaptive and flexible manufacturing solutions. Procedia engineering, 69, 1184-1190. https://doi.org/10.1016/j.proeng.2014.03.108

Reischauer, G. (2018). Industry 4.0 as policy-driven discourse to institutionalize innovation systems in 
manufacturing. Technological Forecasting and Social Change, 132, 26-33.

https://doi.org/10.1016/j.techfore.2018.02.012

Ricciardi, A. (2003). Le reti di imprese. Viaggi competitivi e pianificazione strategica. Franco Angeli.

Rindfleisch, A., O'Hern, M., \& Sachdev, V. (2017). The digital revolution, 3D printing, and innovation as data. Journal of Product Innovation Management, 34(5), 681-690. https://doi.org/10.1111/jpim.12402

Roland, B. (2018). Focus, Supply Chain Planning 4.0.

Romano, P., \& Danesa, P. (2006). Supply Chain Management. La gestione dei processi di fornitura e distribuzione, McGraw-Hill.

Rudtsch, V., Gausemeier, J., \& Gesing, J. et al. (2014): Pattern-based Business Model Development for Cyber-Physical Production Systems. Procedia CIRP, 25, 313-319. https://doi.org/10.1016/j.procir.2014.10.044

Ruessmann, M., Lorenz, M., Gerbert, P., Waldner, M., Justus, J., Engel, P., \& Harnisch, M. (2015). Industry 4.0: The Future of Productivity and Growth in Manufacturing Industries, Boston Consulting Group, 9.

Slack, N., Chambers, S., \& Johnston, R. (2004). Operations Management (4th ed.). Harlow, Pearson Education.

Tan, B., Pan, S. L., Lu, X. H., \& Huang, L. H. (2015). The Role of IS Capabilities in the Development of Multi-Sided Platforms: The Digital Ecosystem Strategy of Alibaba.com. Journal of the Association for Information Systems, 16(4). Article 2. https://doi.org/10.17705/1jais.00393

Tarrow, S. (1995). Bridging the quantitative-qualitative divide in political science. American Political Science Review, 89(2), 471-474. https://doi.org/10.2307/2082444

Tilson, D., Lyytinen, K., \& Sørensen, C. (2010). Digital Infrastructures: The Missing IS Research Agenda. Information Systems Research, 21(5), 748-759. https://doi.org/10.1287/isre.1100.0318

Tiwana, A., Konsynski, B., \& Bush, A. A. (2010). Research commentary-Platform evolution: Coevolution of platform architecture, governance, and environmental dynamics. Information systems research, 21(4), 675-687. https://doi.org/10.1287/isre.1100.0323

Trequattrini, R., Shams, S., Lardo, A., \& Lombardi, R. (2016). Risk of an epidemic impact when adopting the Internet of Things: The role of sector-based resistance. Business Process Management Journal, 22(2), 403-419. https://doi.org/10.1108/bpmj-05-2015-0075

Vandermerwe, S., \& Rada, J. (1988). Servitization of business: adding value by adding services. European Management Journal, 6(4). https://doi.org/10.1016/0263-2373(88)90033-3

Wise, R., \& Baumgartner, P. (1999). Go downstream: the new profit imperative in manufacturing. Harvard Business Review, 133-141.

\section{Copyrights}

Copyright for this article is retained by the author(s), with first publication rights granted to the journal.

This is an open-access article distributed under the terms and conditions of the Creative Commons Attribution license (http://creativecommons.org/licenses/by/4.0/). 